\title{
Competency-Based Curriculum (CBC) in Kuwait: from the Ideal to Real
}

\author{
Taiba Sadeq ${ }^{1}$, Rahima Akbar ${ }^{1} \&$ Fatma Al Wazzan ${ }^{2}$ \\ ${ }^{1}$ Department of English language, College of Basic Education, Public Authority for Applied Education and \\ Training, Ardhiya, Kuwait \\ ${ }^{2}$ Language Center, Authority for Applied Education \& Training, Kuwait \\ Correspondence: Rahima Akbar, Department of English language, College of Basic Education, Public Authority \\ for Applied Education and Training, Ardhiya, Kuwait.
}

This research was funded by the Public Authority for Applied Education \& Training (BE-19-05).

Received: October 26, 2020

Accepted: November 16, 2020

Online Published: December 2, 2020

doi: $10.5539 /$ elt.v14n1p1

URL: https://doi.org/10.5539/elt.v14n1p1

\begin{abstract}
Following the steps of countries known for their rigorous education systems, and under the supervision and recommendations of the World Bank in 2015/2016, Kuwait placed a considerable budget to instigate a curriculum reform, via the implementation of Competence-Based Curriculum (CBC), which was adapted three years ago. However, the relatively modest outcome was controversial and did not meet the expectations of both policymakers and teachers. This study investigated the factors that hindered progression of CBC in the English curriculum as expressed by ESL teachers in the field. The study utilized a mixed-method design whereby both quantitative and qualitative data were used to fulfill the research objectives. Findings indicate that ESL teachers generally held positive views on CBC, yet several obstacles hindered CBC efficacy in the schools of Kuwait. The study also listed a number of pros and cons of CBC practice in Kuwait. Interviews with stakeholders brought a number of issues of misconduct, if not contained, no curriculum reform would gain the anticipated positive outcomes. Research objectives were addressed as a recommendation for future planning of curriculum change, contributing to the field of study.
\end{abstract}

Keywords: competence-based curriculum, ESL, curriculum change, teachers, Kuwait

\section{Introduction}

We are living in an era of information revolution, whereby information can be reached within the tip of our fingers. Hence, rather than wasting the youths' time and effort in being exposed to the subject content, students need to learn the skill of how to look for the information, how to select the right channels, how to critically appraise the presented information, and how to apply those skills in real-life experiences. In such context, educators have also shifted from a curriculum that is content-based (subject-based curriculum) into one which is skill-based (competency-based curriculum, CBC).

Competency-based learning has first been established in the work of Bloom, John Carroll, and others in the 1960s and 1970s (Bloom, 1956; Ford, 2014; Le, Wolfe, \& Steinberg, 2014; Malan, 2000). It has only been during the recent decade when various educational systems around the globe have started its implementation in their schools and other educational institutes. Nonetheless, full-scale CBC models are still in their infancy phase (Nodine, 2016).

In Kuwait, where the current study is conducted, the education sector suffers from a significant decline in all indicators of global development. Kuwait has been ranked last among the six Gulf countries in the results of "Pearls" tests to measure the reading level of fourth-graders, and the last Gulf ranked in the "TIMS" tests to measure the level of achievement in mathematics and science for the fourth grade. In a series of measures to resolve the problem, Kuwait has finally decided to make a drastic curriculum reform, to follow the steps of countries known for their rigorous education systems. Under the supervision and recommendations of the World Bank in 2015/2016, Kuwait has placed a considerable budget to instigate a curriculum reform, via the implementation of $\mathrm{CBC}$. Unexpectedly though, no tangible progress has been sensed after three years of $\mathrm{CBC}$ 
implementation in the primary and intermediate schools. Teachers, parents, and school administrators have started calls to put $\mathrm{CBC}$ on halt and revisit the situation before further damages occur.

The present study is an attempt to revisit the matter through the lens of the teachers (those who are expected to place the curriculum into practice).

\section{Literature Review}

The term 'curriculum' has been disputedly defined by the scholars and educators in the field. Nevertheless, a useful definition which we prefer to start with has been presented by John Kerr as 'All the learning which is planned and guided by the school, whether it is carried on in groups or individually, inside or outside the school (quoted in Kelly, 1980: 10). As such, a curriculum is comprised of a series of planned experiences, through which learners obtain the learning material as well as the applied learning skills.

Accordingly, the concept of a curriculum entails three main cornerstones, namely students, teachers, and the learning material. Attempts to design a curriculum will be doomed to failure if any of its three cornerstones are overridden. In his highly influential work 'Pedagogy of the Oppressed', Paulo Freire defined educational systems as tools of people in power to institutionalize their dominant values at the expense of the oppressed (teachers) (Armstrong, Henson, \& Savage, 2008). Thus, a curriculum change, by its very nature, would generate complexities of various types and origins. Olaf Jorgenson (2006) described attempts of curriculum developments as quoted by a speaker at one of the conferences as 'moving graveyard, nobody pays much attention until you try to do it!

\subsection{Defining $C B C$}

During the past decade, an influx of teaching strategies and pioneering discoveries about learning processes have proven to be effective, establishing that the-stand-and-deliver model of teaching has become incompatible with today's youth. As we are living in a world of revolutionary information, teachers are expected to extend their roles from information providers into facilitators. Educators should find ways to readdress the students' needs in a world with explosive knowledge through the implementation of meaningful, sustainable changes, to 'rebuild the airplane while they're flying it' (Wagner, 2006).

Competency-based curriculum refers to systems of instruction, assessment, grading, and academic reporting that are based on students' demonstration of the learned knowledge and skills expected be to be learned as students progress through their education (Edglossary, 2014).

The curriculum, which emphasizes the complex outcomes of a learning process (i.e. knowledge, skills, and attitudes to be applied by learners), shifts the focus away from what learners are expected to learn in what used to be traditionally-defined subject content. In principle, such a curriculum is learner-centred, where the learner is hoped to obtain not only the knowledge but also the application of its skills in future life experiences (Botova, 2015).

Theoretically, competency-based education 'is an evolving field with no universally shared definition of what makes a model competency-based' (Le, Wolfe, \& Steinberg, 2014: 4). Because there is no commonly accepted definition, competency-based education 'lacks conformity around standards and theoretical backing,' making it difficult to be implemented consistently in various educational institutes (Gervais, 2016).

Le, Wolfe, and Steinberg (2014) proposed that CBC is theoretically rooted in behaviourist, functionalist, and humanistic approaches, synthesizing between liberal art and vocational education, whereby students are required to learn the theoretical foundations to gain the ability to move from knowledge into practice (Tyler, 1976).

The decision of whether to make a headway toward competency-based curriculum across the countries would certainly entail weighing the benefits and challenges of that move. Thus, educators and policymakers have looked closely into the benefits and challenges of the curriculum. Several key benefits were reported in CBC, including CBC flexibility to suit the individual learner's abilities and time frame; $\mathrm{CBC}$ is also designed to be self-pacing, emphasizing that the outcome is more important than the journey, and arguing that it would enable the student to move slow or fast, without being confined by a set of learning processes. Two important reported strengths of $\mathrm{CBC}$ are, $\mathrm{CBC}$ is designed around competencies needed for future life experiences, ensuring that students are provided with expertise in their chosen fields; $\mathrm{CBC}$ is also claimed to increase student engagement, hence students are more engaged in the material because they have ownership over their learning. As a result, they are empowered because they have control over when, where, and how they learn.

On the flip side, $\mathrm{CBC}$ fits specific types of learners. $\mathrm{CBC}$ environment requires students who are motivated and self-disciplined. Students who never learned to work off deadlines would not thrive; they would more likely fall 
behind. The environment might not be any easier for teachers either, who are expected to decide on which competencies demonstrate mastery, how to adapt their course material for students to move through different speeds, and how to push the struggling students to fit in the new system (Bediako, 2019).

\subsection{Why Teachers' Views Matter}

Fullan states, 'Educational change depends on what teachers do and think - it is as simple and complex as that.' (2007: 117). As such, any system reform, particularly in a curriculum whereby teachers are the implementors as the main stakeholders would be doomed to fail, if teachers were not actively involved in the reform.

Borko (2004) also asserted that a curriculum change would unlikely run smoothly when teachers are simply viewed as practitioners, expected to implement the plans of others. In such cases, failure of curriculum reform is caused by teachers' lack of involvement, hence, lack of ownership for the reform. Previous research has also stated that when teachers collaboratively work in the curriculum reform team, the process will enhance teachers' design expertise, leading to improve quality of the design process and material (Huzinga, Handelzalts, Neiveen \& Voogt, 2014).

In another study, evidence from $14 \mathrm{Ph}$. $\mathrm{D}$. studies was gathered to explore their effect on teachers' abilities to implement the curriculum designs when teachers were involved in the design teams. The findings showed positive outcomes manifested in the curriculum design processes, teachers' knowledge and practice, and the implementation of curriculum change (Voogt, Pieters, \& Handelzalts, 2016).

Curriculum reforms are complex processes, which often fall short of fulfilling their goals (Fullan, 2007; Green, 1980; Stenhouse, 1975; Van den Akker, 2010). Teachers in Netherland, for example, have the legal rights to shape and implement their school-specific curriculum (Kuiper, Van den Akker, Hooghoff, \& Letschert, 2006; Nieveen \& Kuiper, 2012), allowing teachers to design tailored curriculum materials to fit their students' needs (e.g., Ministerie van Onderwijs \& Cultuur en Wetenschap, 2011; Onderwijsraad, 2014; VO-Raad, 2014). However, during the initial stages, when teachers lacked the skills to collaborate in curriculum design, their first few attempts failed. That is to say, providing teachers with the required ownership of a curriculum design might not work to its best. Teachers need to have subject matter knowledge, pedagogical content knowledge, and curriculum design expertise, alongside the provided ownership of the newly implemented curriculum (Nieveen, Van den Akker, \& Resink, 2010; Nieveen \& Van der Hoeven, 2011). For teachers to play a decisive role in curriculum reforms, it is essential to support them in their collaborative design process, to help them tackle design challenges and to develop their design expertise (Handelzalts, 2009; Hardré et al., 2006; Nieveen, Handelzalts, Van den Akker, \& Homminga, 2005).

\subsection{Examples of CBE Implementation in Other Countries}

The literature on CBC implementation across the world tends to be scarce (maybe due to its complex nature), especially in basic education. Africa tends to be among the continents where CBC has been implemented and studied. Generally speaking, reports indicate that teachers in African countries were ill-trained in $\mathrm{CBC}$; policymakers had no clear understanding of CBC too (Kenya National Union of Teachers [KNUT], 2019).

In Nairobi, for instance, a study explored teachers' attitudes towards CBC implementation in the private sector. Findings showed that teachers expressed positive attitudes towards $\mathrm{CBC}$ implementation. However, they also expressed their concerns over limited in-service training, lack of resources, extensive workload, lack of ICT skills and limited parental support, claiming they all hindered effective implementation of CBC. In another study in Kenya, data showed that CBC was not systematically implemented, as teachers were minimally trained on its contents and methods of teaching, which in turn hindered their application of essential knowledge and skills of the curriculum. Additionally, a general lack of adequate approved textbooks for teachers and learners as well as instructional materials, inexperienced parents, and other education stakeholders' involvement in the curriculum reform process, led to the failure of the reform (Ondimo, 2018).

In Tanzania, a study examined how secondary school teachers experienced the implementation of the competency-based curriculum by using a descriptive case study design. Findings indicated that the participants had a limited understanding of the curriculum; they were happy in their teaching profession regardless of competence-based curriculum challenges. One of their key concerns was the lack of participation in curriculum design and implementation, lack of quality textbooks and lastly, insufficient motivation to implement CBC (Muneja, 2015).

In Indonesia, $\mathrm{CBC}$ shifted the role of the teacher into an educational facilitator where teachers are required to encourage learners to set goals for their learning, and support learners to retrieve and retain knowledge to be used in practices which help to develop habits of lifelong training (Masdugi, 2006). 
In Hong Kong, English competency is known as one of the crucial skills in various social contexts. In a tertiary educational setting, English courses do not focus solely on the development of the four language skills; rather, they emphasize the application of the English language for academic use or instrumental use. The effectiveness of competency-based ESL teaching and learning situation of a group of 70 pre-service teachers of Chinese recommended incorporating local $\mathrm{CBC}$ curriculum, with suitable instructional and assessment practices and policies (Har Wong, 2008).

\subsection{The Case of Kuwait}

The beginning of the third millennium brought about constant debates concerning key competences as an overarching set of trans-disciplinary outcomes of learning to be achieved by every student by the end of primary education (e.g. European Commission, 2005).

Singer, Samihaianb, Holbrookc \& Crisan (2014) described Kuwait as a state offering an educational context that combines strong religious traditions, old fashioned ways of teaching, rich potentiality of resources, and a modern vision to reform education for a highly competitive and prosperous Kuwaiti society. The Kuwaiti government has laid its vision to become a future financial international centre in 2013, yet past achievements on international assessment tests were not appropriate to meet these expectations. The participation of Kuwait in TIMSS and PIRLS 2011 assessments showed very poor results in Mathematics and Sciences, and the lowest results in reading (Singer et al., 2014). Within that context, urgent calls have been instigated from the parliament and the government to reassess Kuwait's National Curriculum in the light of modern curriculums globally implemented in developed countries. In response, The World Bank attempted to tailor a competency-based curriculum that should bridge the gap between the integration of competencies and separation of subject contents. Thus, they presented a detailed design of how to tackle the four main subjects, namely, languages (Arabic \& English), maths, and science.

In the year 2016, a competency-based curriculum has been put into effect, following a scheduled implementation that starts with primary schools and gradually moves into intermediate and secondary schools. Only within three years of $\mathrm{CBC}$ implementation, calls from parents, teachers, and school principals, to put $\mathrm{CBC}$ on halt, have become widely heard in the country. The media has also started to pinpoint the issue with voices of pro-or-anti CBC. According to Al-Qabas (a well-known newspaper in the country), implementation of CBC was ill-planned, implemented with no clear vision of neither the process nor the outcome (Alfailakawi, March, 2018). Also in AL-Rai (another local newspaper), an article claimed that $\mathrm{CBC}$ has been cancelled since the beginning of the academic year 2019/2020, yet the decision has never been officially announced by the Ministry of Education (MOE); the author of the article proposed a legitimate query, "does this indicate that the wheel of curriculum reform has come to an end?" (Alturky, April, 2019).

\section{Research Scope}

In the present study, we attempt to explore ESL teachers' attitudes towards CBC after three years of its implementation in the primary schools of Kuwait. The study aims to answer the following research questions:

1. How satisfied were ESL teachers with the overall outcomes of CBC implementation in Kuwait?

2. What were the main obstacles ESL teachers faced during $\mathrm{CBC}$ implementation in Kuwait?

3. What are the views of educational policymakers on the practice of $\mathrm{CBC}$ after three years of its implantation in Kuwait?

The study mainly focusses on how ESL teachers perceive CBC practice in the primary schools of Kuwait over the last three years.

\subsection{Research Designs}

The study was divided into two phases over four months of the school year (2018-2019). During the first phase, the study employed a questionnaire method to elicit teachers' perceptions and attitudes concerning their roles during the use of $(\mathrm{CBC})$. The questionnaire results were used to answer questions $1 \& 2$ under the scope of the study. Ambivalent attitudes were further investigated through focus group discussion (comprised of a group of 5 ESL female teachers to gain further insight into the matter). Unfortunately, no male teachers accepted to participate in the interviews on the matter.

In phase 2, semi-structured interviews were administered with reachable high ranked educators and policymakers from the Ministry of Education in Kuwait. The data were analyzed qualitatively to answer question 3 of the study's research questions. 


\subsection{Sampling Procedures}

Before collecting data, an approval had to be obtained from the Ministry of Education to access the selected schools. Researchers used purposive sampling for both phases. In phase one, 81 teachers were selected from the English Language Department in two primary schools, one for boys and another for girls to fill in the questionnaires. Following that, the researchers administered a group discussion with five ESL teachers who have agreed to participate in a follow-up investigation of the issue.

Semi-structured interviews were conducted via Skype with the Head of the English Department at one of the schools of Kuwait (HOD), and the English subject Chief supervisor at the Ministry of Education (MOE) in Kuwait. It is worth mentioning here that several attempts to reach highly ranked personnel from MOE have been unsuccessful due to their refusal to provide the researchers with any information on the topic, claiming the sensitivity of the issue under discussion.

\section{Study Results}

\subsection{Quantitative Phase Results}

The study investigates CBC as employed in the schools of Kuwait. Two main aspects of CBC deployment have been explored. The first is teachers of English satisfaction with $\mathrm{CBC}$ approach after three years of utilizing it in the primary schools of Kuwait. The second is the obstacles faced by teachers in implementing the curriculum.

81 English teachers participated in the study, in which they presented their views on the two above main dimensions of the questionnaire. Age-wise, the participants showed a distribution of $33 \%$ of teachers below the age of $30,48 \%$ between $31-41,16 \%$ between $42-51$, and only $2.5 \%$ beyond the age of 51 . Almost two-thirds of our respondents were female teachers (72\%), while about $30 \%$ were male English teachers. Note that nearly $80 \%$ of teachers teaching the primary stage in Kuwait are female. As for the respondents' years of experience in teaching, our data included $19 \%$ of teachers with less than three years of experience, $40 \%$ with those having $4-10$ years of experience, and a majority of $51 \%$ having more than ten years of teaching.

Two main statistical processes were conducted to fulfil the present study's objectives. The first was a comprehensive investigation of teachers' mean scores along the questionnaire items concerning the two focal points, namely teachers' satisfaction level and their views on a list of obstacles that might have impeded CBC employment in their teaching. This step was followed by a more in-depth investigation of three independent variables of respondents' age, gender, and years of experience.

The first set of statistical analyses presents high satisfaction levels with items expressing ' $\mathrm{CBC}$ easy evaluation scheme,' 'CBC enrichment of the educational system,' and 'Teachers' adequate preparation to implement CBC'; moderate satisfaction levels for items of ' $\mathrm{CBC}$ suits different learning styles,' ' $\mathrm{CBC}$ builds the student character,' 'CBC suits low learners and high flyers,' 'CBC transforms the student from a recipient into a participant,' and 'CBC develops the student's critical thinking and analytical skills.' The results also show dissatisfaction with $\mathrm{CBC}$ when compared to conventional curriculum approaches as illustrated in Figure 1.

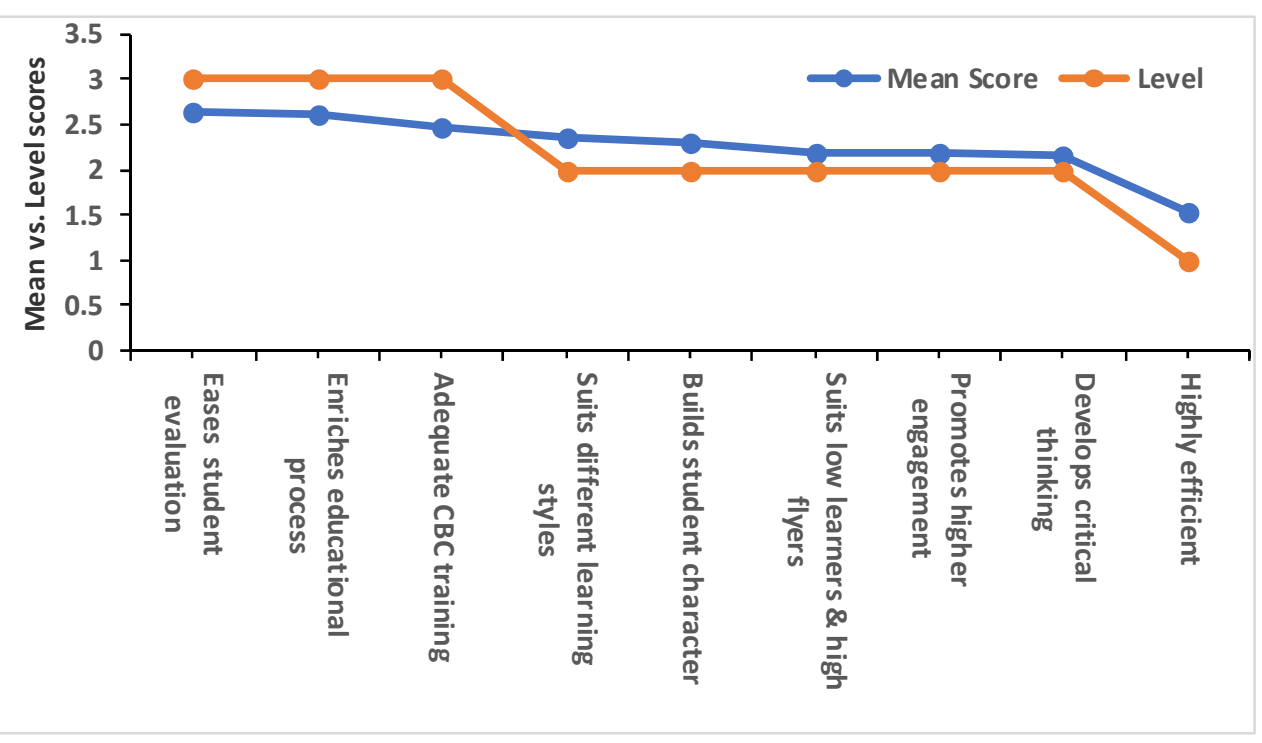

Figure 1. Teachers' Satisfaction Level with CBC 
Results of the sample's views on the listed obstacles associated with CBC implementation (presented in Figure 2) show a high level of agreement on 'the general refusal for change,' a moderate agreement with 'Teachers' insufficient training on $\mathrm{CBC}$ ' and 'Parents' lack of awareness with $\mathrm{CBC}$.' The sample, however, tends to disagree with 'the unfairness of $\mathrm{CBC}$ evaluation system,' 'the clash between the supervisors' and $\mathrm{CBC}$ vision,' 'constant change of $\mathrm{CBC}$ marking scheme,' Parents' dissatisfaction with $\mathrm{CBC}$,' 'Dealing with large number classes,' 'Dealing with a huge number of competencies' and 'CBC causing a distraction from the main teaching objectives'.

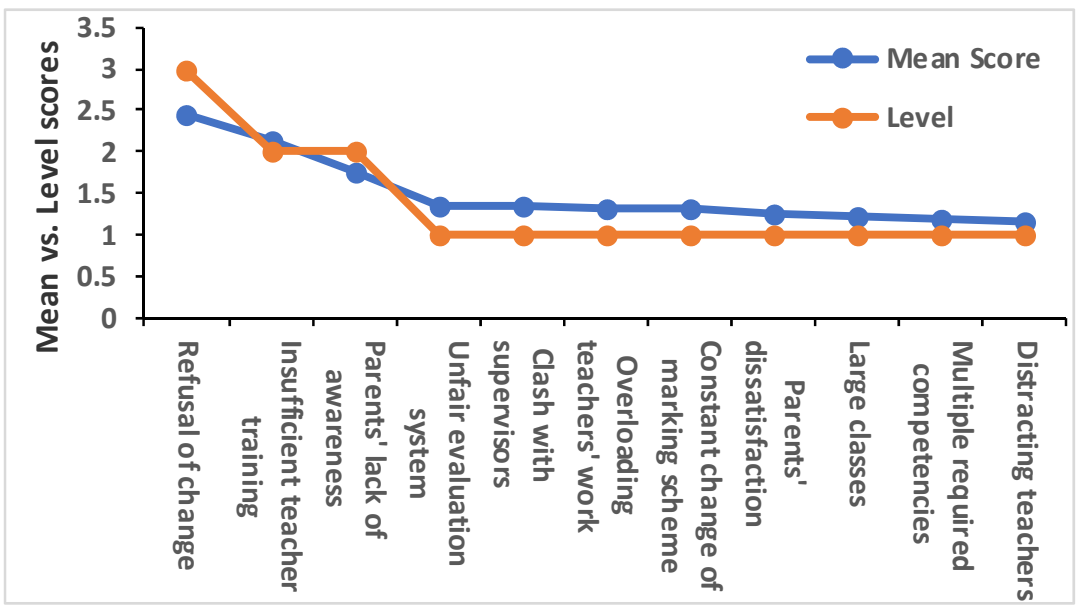

Figure 2. Teachers' agreement level on claimed CBC Obstacles

As for the second set of analyses, the present study's results show some variability across three hypothetical independent variables of age $(>30,31-41,42-51,<52)$, gender, and years of experience ( $>3$ years, $4-10,<10$ years). The relationship between the dependent variables (including the two lists of questionnaire items in relation to teachers' satisfaction and presented list of obstacles in CBC implementation) and the independent variables were obtained using ANOVA tests of variance in SPSS at a chosen level of significance of $>0.05$.

It was found that gender had only a significant effect on such variables as 'the overloading teachers' work' $(0.03)$ and 'unfairness of CBC evaluation system' (0.04). Females mostly claimed that $\mathrm{CBC}$ increased the load of the work for them, whereas male teachers denied any increase in their workload. Females also showed more agreement on 'the unfairness of CBC evaluation system' compared to males.

Teachers' age also had a significant effect on their views of 'being fully prepared to apply CBC efficiently' (0.034), 'the clash between supervisors and CBC vision' $(0.00)$, as well as 'parents' lack of awareness on CBC' $(0.041)$. In this regard, the majority of teachers aged under 41 years old, and all of those aged above 52 considered themselves as being fully prepared to apply CBC efficiently. Teachers falling in the age group (41-51) showed somewhat inconsistent views on their level of preparation. No significant effect on any other dependent variables and age had been found. All teachers aged below 41 years viewed no clash between the supervisors' practices and $\mathrm{CBC}$ overall vision. From another point of view, the oldest group of teachers $(52+)$ considered the 'clash between supervisors' views and the vision of $\mathrm{CBC}$ as a possible obstacle that reduces the efficiency of $\mathrm{CBC}$ implementation. Once again, the views of teachers falling within the age group of 42-51 were rather inconsistent. Regarding 'parents' lack of awareness of CBC,' teachers falling within the age of 31-41 were scattered, though the majority tended to either disagree or agree to a certain extent. Teachers aged 42-51 did not deny the adverse impact of 'parents' lack of awareness on CBC.' All teachers beyond the age of 52 showed partial agreement towards the item.

As for the study's third independent variable, namely teachers' years of experience in teaching, the factor showed significance concerning two dependant variables, namely 'insufficient teachers' training' $(0.03)$ and 'the clash between supervisors' views and CBC overall vision' (0.001). Teachers with less than three years of experience were less likely to agree on the item stating that teachers needed adequate training on $\mathrm{CBC}$ to raise the curriculum efficiency. From another point of view, the majority of teachers who had 4-10 years of experience believed that adequate training for teachers would enhance the efficiency of $\mathrm{CBC}$ implementation. Almost all the teachers with less than ten years of experience asserted that the clash between supervisors' views and $\mathrm{CBC}$ vision was never an obstacle that hindered the efficiency of $\mathrm{CBC}$. Teachers with $10+$ years, however, tended to refuse the idea. 


\section{Discussion}

Being in existence for nearly six decades, it would be unwise to claim $\mathrm{CBC}$ inefficacy without exploring the reasons behind its claimed failure in reaching the anticipated fruitful gains of the approach. With the recent dispute in the country over CBC efficacy as implemented in primary schools in Kuwait, this study is an ambitious attempt to explore issues that most likely led to its failure, namely, teachers' satisfactory levels towards $\mathrm{CBC}$, being one of the three pillars of any curriculum approach, teacher, student, and teaching material. We will then move forward into teachers' views on several obstacles that have been repeatedly associated with CBC implementation as voiced by teachers who have themselves survived through the actual implementation of the approach in the schools of Kuwait.

\subsection{Teachers'Satisfactory Levels with CBC Claimed Features}

Our findings suggest that ESL teachers hold high-moderate satisfactory levels towards CBC in general after three years of its implementation in the primary schools of Kuwait. Teachers of English in the primary schools of Kuwait have highly ranked CBC as achieving 'an easy process of learners' evaluation' as well as a tool that 'enriches the whole educational system.' At the same time, they were highly satisfied with the teachers' preparation and training' for $\mathrm{CBC}$ utilization in the education system in Kuwait. On the other hand, the subjects of the present study have shown moderate satisfactory levels towards 'the relative appropriateness of $C B C$ to students with different learning styles and learning abilities (low vs. high achievers)', 'developing the learner's character and transforming the learner from a passive recipient into an active participant'. Nevertheless, our sample of English teachers has been satisfied to a lesser degree with whether ' $C B C$ develops learners' critical/analytical thinking', and 'CBC's efficiency with previous conventional approaches for teaching'. Variability in relation to teachers' age, years of experience, and gender has not been attested for along the satisfactory dimension of the questionnaire items.

\subsection{Teachers' Views on Claimed Obstacles of CBC as Voiced by Experienced Entities}

As explained earlier, one of the main objectives of the present study is to tackle teachers' views on $\mathrm{CBC}$ obstacles as voiced amongst the Kuwaiti educational system. Our findings suggest that the sample tends to highly associate $\mathrm{CBC}$ inefficiency in Kuwait with the community's general refusal of change due to its highly conservative nature. To a lesser degree, the so-called failure of $\mathrm{CBC}$ has been related to insufficient teacher training prior to and during the implementation of the curriculum. It should be noted here that a discrepancy surfaced between this finding and a prior finding associated with the sample's satisfactory levels to a similar aspect of CBC, namely, 'teachers being fully prepared to utilize CBC in their teaching.' The discrepancy will be further investigated in the second phase of the project. A deeper investigation of the views held by English teachers towards the listed obstacles in the questionnaire has reflected significant variability of the informants' views along the item of ' $C B C$ evaluation unfairness' and 'teachers' being overloaded with work' across the informants' gender. Female teachers tend to consider the two items as legitimate obstacles when compared to male teachers.

From another point of view, the age of the informant has also presented variability in relation to 'teachers' insufficient training,' 'the clash between supervisors and CBC vision', and 'parents lack awareness in $C B C$ '. It looks like teachers who fall in the age group of 31-41 seemed to be inconsistent in their views on how fully prepared they are in utilizing $\mathrm{CBC}$ when compared to teachers above the age of 52 (viewing the obstacle as legitimate) and below 31, who tend to disagree with them. With regard to the obstacle of the clash between supervisors and $C B C$ vision, younger teachers tend to deny the claim, teachers falling in the middle age group show inconsistent views, while the older group of teachers found it an issue that raises concerns.

As for 'parents' lack of awareness,' the younger age group tends to be inconsistent, while the middle age group does not deny its negative effect on the outcomes of CBC implementation.

Additionally, less experienced teachers (below three years of experience) denied the insufficiency of training in $\mathrm{CBC}$ as well as the clash between supervisors and $\mathrm{CBC}$ vision as possible obstacles that might have hindered the curriculum from gaining its benefits in Kuwait. The finding could possibly explain the ambiguity we encountered when we reached somewhat discrepant results in relation to the two different items pertaining to the same issue on the questionnaire.

To sum up, ESL teachers' views towards $\mathrm{CBC}$ implementation in Kuwait presented the following tendencies:

a. ESL teachers hold high-moderate satisfactory levels towards $\mathrm{CBC}$ in general after three years of its implementation in the primary school of Kuwait. 
b. ESL teachers highly ranked $\mathrm{CBC}$ as achieving an easy evaluation system and a proper tool to enrich the overall educational system.

c. ESL teachers are highly-to-moderately satisfied with the teachers' preparation and training for CBC utilization in the education system in Kuwait.

d. ESL teachers hold moderate satisfactory levels towards the relative appropriateness of CBC to students with different learning styles and learning abilities (low vs. high achievers).

e. ESL teachers are moderately satisfied that CBC develops the learner's character and transforms the learner from a passive recipient into an active participant.

f. ESL teachers are dissatisfied that CBC develops learners' critical/analytical thinking when compared to conventional approaches for teaching.

g. A significant obstacle that led to CBC lack of efficiency is the community's general refusal of change due to its highly conservative nature.

$h$. A second main obstacle is teachers' lack of training pre-and-during $\mathrm{CBC}$ implementation.

$i$. Only female teachers find $\mathrm{CBC}$ evaluation unfair and 'teachers' overloaded with work' as two additional obstacles that might have affected CBC efficacy.

j. Older teachers found 'insufficient training of teachers' a legitimate obstacle that could have led to CBC failure.

k. Older teachers found "the clash between supervisors and $\mathrm{CBC}$ vision also a legitimate obstacle that might have led to $\mathrm{CBC}$ failure.

l. Middle age group teachers consider 'parents' lack of awareness in $\mathrm{CBC}$ ' an obstacle that hinders the success of $\mathrm{CBC}$ implementation.

\subsection{Focus-Group Interviews Findings via WhatsApp}

A group of five female teachers of English participated in the focus group interviewing sessions that were held for a week on the WhatsApp application. The two main researchers led the interviewing sessions via WhatsApp group discussions by presenting the following key question:

Based on your experience in utilising $C B C$ in your classrooms, how is $C B C$ different from other teaching methods that you know of? And how did CBC affect the overall education system in Kuwait?

Responses revealed very positive views on $\mathrm{CBC}$ had it been implemented properly as stated, ' $\mathrm{Had} C B \mathrm{C}$ implemented properly, it could've truly reflected the standards of both the student and teacher'. The view was also endorsed by all members of the group discussion. In their elaboration on the issue, the participants engaged in mentioning $\mathrm{CBC}$ pros and cons (reported in Table 1). It should be noted at this point that the views listed in Table 1 represent female Kuwaiti teachers' views only. The researchers' attempts to access male teachers' views were unsuccessful due to their refusal of engaging in any sort of group discussions.

Table 1. CBC pros \& cons as claimed by English teachers' sample

\section{CBC Pros}

1. Flexible for both teachers and students.

2. Keeps into consideration individual learning abilities and skills

3. Develops and integrates the four language skills at a time.

4. Fulfils the psychomotor skills of the students as it requires the students to move around, create groups and accomplish tasks.

5. $C B C$ is definitely suitable for children who have the love and the passion to learn new things. Unfortunately, those are a minority in our schools!

\section{CBC Cons}

$C B C$ is vague to teachers due to the lack of teachers' preparation in its implementation

Future teachers have never been exposed to $C B C$ in any of their teaching method courses. So, the wheel of providing the schools with unqualified teachers in CBC implementation keeps on moving.

Supervisors assigned by the Ministry of Education to lead practicing teachers seem to have no idea about $C B C$. They, therefore, use their own experience of how they learned and taught English using conventional teaching curriculums.

$C B C$ should be reflected in the student's assessments. Implementation of conventional tests invalidates $C B C$ in the eyes of teachers, students as well as parents.

When teachers are overwhelmed with the requirements of $C B C$, many give up and start manipulating the system up to a point where they give their students a room to cheat and gain grades not reflect their actual abilities. 


\subsection{Structured Interviews with Policymakers}

Attempts to interview top policymakers in the Ministry of Education in Kuwait were unfortunately unsuccessful as they claimed they would not be able to disclose any information as per the confidentiality rules and regulations of the institution. We, therefore, approached two educators whose work is more of a technical nature (The head of the English department in a primary school for girls HoD \& the chief supervisor of the English subject). The following four key questions were asked to lead the interviews (See the detailed responses from both interviewees in table 2 in the appendix).

1. CBC should be implemented using top-down rather than bottom-up procedures. In other words, Supervisors and head teachers of the subjects should be ideally introduced to $C B C$ in practice in countries where the curriculum has been successfully implemented (Workshops). CBC should also be incorporated in the courses of teaching methods at the colleges of Education. The change is expected to be led by experienced professors in the field.

Have you tried any of these procedures before you come to a final decision on the inefficiency of $C B C$ in Kuwait?

2. Have you considered the gradual implementation of $C B C$ rather than the abrupt implementation all over the schools of Kuwait?

3. Have you considered providing teachers with an ongoing training on $C B C$ ?

4. Have you tried minimising other administrative chores on teachers to find out whether it will lead to the success of $C B C$ ?

Responses to question 1 revealed that the practice moved in a top-down hierarchy, starting with the supervisors, moving to headteachers, and finally, to subject teachers. Teachers were only exposed to local workshops in Kuwait, which, as pointed out by HOD, led to problems encountered in utilizing CBC by HODs, who 'weren't competent to train and follow.' From another point of view, the Chief supervisor claimed that CBC was implemented using top-down rather than bottom-up procedure, as 'supervisors and head teachers received their training through cascading techniques' where the 'core team' was exposed to intensive workshops designed by the World Bank Organization, which drew 'the philosophy, the guidelines, and the new terminologies, in addition to the new assessment and evaluation ways.' Members of the 'core team' were the only staff who had the opportunity to see the proper practice of $\mathrm{CBC}$ worldwide. According to the chief supervisor, the core team does not include teachers, headteachers, or supervisors, who were never exposed to the actual practice of $\mathrm{CBC}$ in countries where the $\mathrm{CBC}$ implementation proved to be successful. In other words, the technical team who is directly involved in teaching was never provided with any proper training on CBC implementation. When taking the responses of the teachers in the group discussion sessions into account, it looks like supervisors, senior, and junior teachers had no expertise to turn on the wheel. Besides, teachers have never learned CBC in their undergraduate curricula. As a result, the technical team had neither a proper theoretical nor practical background to implement $\mathrm{CBC}$ in the schools of Kuwait.

As for the proper implementation of $\mathrm{CBC}$ in the schools of Kuwait, the headteacher explained that the implementation of $\mathrm{CBC}$ had followed the recommendations of the experts from the World Bank Organization, to be initially implemented across the five grades of the primary stage, followed by the first academic year in both intermediate and secondary stages, with the intention to keep on expanding it into the following academic year until it covers all the stages and grades of the education system in Kuwait. From the Chief supervisor's point of view, the plan went perfectly well, especially in the primary stage, where both teachers and students became very creative and developed necessary learning skills that were never touched upon during the traditional teaching methods.

Training sessions were local, led by HODs, who were incompetent and relied on 'individual efforts,' especially as CBC 'needed more time, less classes to teach, and less administrative chores to fulfil.' According to the chief supervisor, there was an ongoing training that was included in the 'CBC document that described the continuous professional development and can be applied at schools on a weekly basis.' Administrative chores, however, were never minimised, 'despite multiple requests' from the advisory department at MOE. Interviewed teachers have also reported, 'When teachers are overwhelmed with the requirements of $C B C$, many give up and start manipulating the system up to a point where they give their students a room to cheat and gain grades that do not reflect their actual abilities.' The fact that neither the head teachers, nor the Chief supervisors, were able to minimize the administrative work for teachers being the actual implementers of $\mathrm{CBC}$ in classes, seems to have a major role in the reported failure of the system. 


\section{Conclusion}

The study investigated ESL teachers' views of CBC practice in the primary schools of Kuwait during the academic years of 2016-2019. The findings reflect that teachers generally find CBC a satisfactory teaching and learning curriculum, a proper tool that may enrich the whole education system, which accommodates learners of various learning styles and levels, yet would not develop their higher thinking and analytical skills when compared to other conventional curriculums.

In Kuwait, $\mathrm{CBC}$ implementation has failed due to many obstacles including, communities' general tendency to obstruct changes due to the Kuwaiti conservative nature, alongside the lack of teachers' efficient training pre-and-during $\mathrm{CBC}$ implementation. Added to that, female teachers (the majority of the study's sample) considered $\mathrm{CBC}$ assessment system as 'unfair' and teachers being 'overloaded with chores other than the teaching process' as two obstacles that might have led to the failure of $\mathrm{CBC}$ implementation. Older teachers (52+) also considered 'the clash between CBC vision and supervisors' views and recommendations' as another obstacle encountered during the practice.

For Kuwaiti ESL teachers, $\mathrm{CBC}$ is a flexible system that accommodates learners of various learning styles and abilities. CBC also helps to develop learners' four linguistic skills, enhances children's psychomotor skills, and improves both teachers' and students' thinking skills. Nevertheless, CBC requires an atmosphere of less workload, efficient training, and learners who have a passion for learning. Assessments should also be in line with the overall objectives of CBC. It is worth a mention that the data elicited from focus group interviewing sessions engaged female Kuwaiti teachers only. Thus, it is recommended to include male Kuwaiti teachers elaborated views on $\mathrm{CBC}$ practice in the primary schools of Kuwait in future investigations of the topic.

Despite claims of providing enough training for teachers pre-and during $\mathrm{CBC}$ implementation, the Chief supervisor disclosed that teachers were exposed to local training sessions only in Kuwait, by HODs who themselves, as stated by one of them, 'weren't competent to train and follow'!. The 'core team,' as stated, was given the chance to observe how $\mathrm{CBC}$ was implemented across the globe. In the Kuwaiti setting, top leaders and policymakers are known to empower the powerful and de-power the powerless, practicing exactly how Paulo Freire described 'educational systems as tools of people in power to institutionalize their dominant values at the expense of the oppressed (teachers).' Unless teachers in Kuwait gain the required autonomy and training, a curriculum such as $\mathrm{CBC}$ would never gain the expected outcomes.

All in all, the present research suggests that $\mathrm{CBC}$ is a powerful tool that was implemented in the wrong place and at the wrong time. Learners have never learned to be self-disciplined, work out off deadlines with the required enthusiasm to learn. Teachers were not placed at any more favourable position either; teachers were ill-trained and weakened by people in power, who abused the system to gain personal benefits via experiencing free journeys across the globe at the price of the actual implementors (regular classroom teachers).

\section{Acknowledgment}

We would like to express our special thanks to the Public Authority for Applied Education and Training for supporting and showing keen interest in this study. We would also like to extend our sincere gratitude to the chief supervisor of the English language at the Ministry of Education, and a primary school Head of the English Department for providing us with such constructive information. Last and not least, we greatly appreciate the time and effort spent during the group discussions with five enthusiastic teachers of English whose time and efforts during their participation in the focus group interview sessions brought up some valuable findings to this work.

\section{References}

Al-Failakawi, A. (2018). Remarks on Competency-based Curriculum. Alqabas newspaper article. Retrieved from https://qabas.news/507493

Al-Turkey, A. (2019). Competency-based Curriculum on halt...Is it the end of curriculum reform? Alrai newspaper rticle. Retrieved from https://www.alraimedia.com/article/844821/محليات/منهج-الكفايات_توقف_-_فهل_انتهت_رحلة_النطوير

Armstrong, D. G., Henson, K. T., \& Savage, T. V. (2008). Teaching Today: An Introduction to Education (8th ed.). New York: Pearson.

Bediako, S. (2019). Models and concepts of curriculum implementation, some definitions and influence of implementation. In Conference of curriculum change and evaluation. Retrieved from https://www.researchgate.net/deref/http\%3A\%2F\%2Fdx.doi.org\%2F10.13140\%2FRG.2.2.17850.24009 
Bloom, B. S. (1956). Taxonomy of educational objectives. Handbook 1. Cognitive domain. New York. McKay. Retrieved from https://b-ok.cc/book/1102769/6eea1e

Borko, H. (2004). Professional development and teacher learning: Mapping the terrain. Educational Researcher, 33(8), 3-15. https://doi.org/10.3102/0013189X033008003

Botova, Y. (2015). The history of development of competency-based Education. European Scientific Journal, Special edition, 1. Retrieved from https://www.eujournal.org/index.php/esj/article/view/5728

European Commission. (2005). Proposal for a Recommendation of the European Parliament and of the Council on Key Competences for Lifelong Learning, Council of the European Union, 11 November 2005. Retrieved from https://www.ghettoradio.co.ke/knut-says-teachers-are-not-prepared-for-competency-based-curriculum/

Ford, K. (2014). Competency-based Education: History, Opportunities, and Challenges. Center for Innovation in Learning and Student Success. Univ. of Maryland University College. Retrieved from https://www.researchgate.net/deref/http\%3A\%2F\%2Fdx.doi.org\%2F10.13140\%2FRG.2.1.4679.0885

Fullan, M. (2007). The new meaning of educational change (4th ed.). New York: Teachers College Press.

Gervais, J. (2016). The operational definition of competency-based education. The Journal of Competency Education. https://doi.org/10.1002/cbe2.1011

Green, E. L. (1980). The independent learning in science model of school-based curriculum development. In J. Eggleston (Ed.), School-based curriculum development in Britain: A collection of case studies (pp. 14-40). London: Routledge \& Kegan Paul. https://doi.org/10.4324/9780429454622-2

Handelzalts, A. (2009). Collaborative curriculum design in teacher design teams (Doctoral dissertation). University of Twente, Enschede, The Netherlands. https://doi.org/10.3990/1.9789036528634

Har Wung, R. M. (2008). Competency-based English Teaching and Learning: Investigating Pre-service teachers of Chinese's Learning Experience. Porta Linguarum, 9, 179-198. Retrieved from https://files.eric.ed.gov/fulltext/ED504222.pdf

Hardré, P. L., Ge, X., \& Thomas, M. K. (2006). An investigation of development toward instructional design expertise. Performance Improvement $\quad$ Quarterly, https://doi.org/10.1111/j.1937-8327.2006.tb00385.x

Huizinga, T., Handelzalts, A., Neiveen, N., \& Voogt, J. (2014). Teacher involvement in curriculum design: Need for support to enhance teachers' design expertise. Curriculum Studies, 46(1). https://doi.org/10.1080/00220272.2013.834077

Jorgenson, O. (2006). Why Curriculum Change Is Difficult and Necessary. In. National Association of Independent Schools $\quad$ (NAIS). Retrieved from https://www.nais.org/magazine/independent-school/summer-2006/why-curriculum-change-is-difficult-andnecessary/

Kelly, A. V. (1983). The Curriculum. Theory and practice 4e. London: Paul Chapman.

Kuiper, W., Van den Akker, J., Hooghoff, H., \& Letschert, J. (2006). Curriculum policy and school practice in a European comparative perspective. In J. Letschert (Ed.), Curriculum development re-invented. Proceedings of the invitational conference on the occasion of the 30 years SLO 1975-2005. Leiden, the Netherlands, 7-9 December 2005 (pp. 56-77). Enschede, The Netherlands: SLO. Retrieved from https://research.utwente.nl/en/publications/curriculum-policy-and-school-practice-in-a-european-comparati ve-p

Le, C., Wolfe, R. E., \& Steinberg, A. (2014). The past and the promise: Today's competency education movement. Boston: Jobs for the Future.

Malan, S. P. T. (2000). The "new paradigm" of outcomes-based education in perspective. Journal of Family Ecology and Consumer Science, 28, 22-28. Retrieved from https://www.researchgate.net/deref/http\%3A\%2F\%2Fdx.doi.org\%2F10.4314\%2Fjfecs.v28i1.52788

Masdugi, H. (2016). The Competency-based Curriculum of English Subject for Senior High School in Indonesia: A Critical Evaluation. Journal Humanitas, 1(2), 56-68.

Ministerie van onderwijs, \& Cultuur en Wetenschap. (2011). Leraar 2020-een krachtig beroep! [Teacher 2020-a powerful profession]. Den Haag: Minsterie van Onderwijs, Cultuur en Wetenschap. Retrieved from https://www.rijksoverheid.nl/documenten-en-publicaties/kamerstukken/2011/05/23/actieplan-leraar-2020.ht 
$\mathrm{ml}$

Muneja, M. (2015). Secondary school teachers' implementation of the competency-based curriculum in the Arusha region, Tanzania (Master degree thesis). University of South Africa, November 2015. Retrieved from https://uir.unisa.ac.za/bitstream/handle/10500/19940/dissertation_muneja_ms.pdf?isAllowed=y\&sequence=

Nieveen, N., \& Kuiper, W. (2012). Balancing curriculum freedom and regulation in the Netherlands. European Educational Research Journal, 11(3), 357-368. https://doi.org/10.2304/eerj.2012.11.3.357

Nieveen, N., \& Van der Hoeven, M. (2011). Building the curricular capacity of teachers: Insights from the Netherlands. In P. Picard, \& L. Ria (Eds.), Beginning teachers: A challenge for educational systems CIDREE yearbook 2011 (pp. 49-64). Lyon, France: ENS de Lyon, Institut français de l'Éducation.

Nieveen, N., Handelzalts, A., Van den Akker, J. J. H., \& Homminga, S. (2005). Teacher design teams: A scenario for school-based curriculum innovation. Paper presented at the ECER, Dublin, Ireland. Retrieved from https://www.researchgate.net/deref/http\%3A\%2F\%2Fdx.doi.org\%2F10.1080\%2F13803611.2016.1247724

Nieveen, N., Van den Akker, J. J. H., \& Resink, F. (2010). Framing and supporting school-based curriculum development in the Netherlands. In E. H. Law, \& N. Nieveen (Eds.), Schools as curriculum agencies: Asian and European perspectives on school-based curriculum development (pp. 273-283). Rotterdam, The Netherlands: Sense Publishers. https://doi.org/10.1163/9789460912818_017

Nodine, T. R. (2016). How did we get here? A brief history of competency-based higher education in the United States. The Journal of Competency-Based Education, 1(1), 5-11. https://doi.org/10.1002/cbe2.1004

Ondimu, S. M. (2018). Teachers' preparedness for for implementation of competency-based curriculum in private pre-schools in Dagoretti North sub-county, Nairobi, City county. Retrieved from https://erepository.uonbi.ac.ke/handle/11295/104613?show=full

Singer, F. M., Samihaianb, F., Holbrookc, J., \& Crisan, A. (2014). Developing a competence-based curriculum for the 21st century: the case of Kuwait. Procedia - Social and Behavioral Sciences, 128, 475-481. https://doi.org/10.1016/j.sbspro.2014.03.191

Stenhouse, L. (1975). An introduction to curriculum research and development. London: Heinemann Educational Books. Retrieved from https://books.google.com/books/about/An_introduction_to_curriculum_research_a.html?id=LQsNAQAAI AAJ

Tyler, R. W. (1976). Perspectives on American education: Reflections on the past...challenges for the future. Chicago, IL: Science Research Associates INC. Retrieved from https://eric.ed.gov/?id=ED130919

Van den Akker, J. J. H. (2010). Building bridges: How research may improve curriculum policies and classroom practices. In S. Stoney (Ed.), Beyond Lisbon 2010: Perspectives from research and development for education policy in Europe (CIDREE Yearbook 2010) (pp. 175-195). Slough, UK: NFER. Retrieved from https://research.utwente.nl/en/publications/building-bridges-how-research-may-improve-curriculum-policie s-and

Voogt, J., Pieters, J. M., \& Handelzalts, A. (2016). Teacher collaboration in curriculum design teams: effects, mechanisms, and conditions. Educational Research and Evaluation, 22(3-4), 121-140. https://doi.org/10.1080/13803611.2016.1247725

VO-Raad. (2014). Klaar voor de toekomst! Samen werken aan onderwijskwaliteit. Sector akkoord VO 2014-2017 [ready for the future! Collaborating on the quality of education. Sectoral agreement secondary education 2014-2017]. VO-Raad: Den Haag.

Wagner, T. (2006). Presentation at the Hawaii Executive Conference, March 20, 2006, Kanuela, HI.

\section{Copyrights}

Copyright for this article is retained by the author(s), with first publication rights granted to the journal.

This is an open-access article distributed under the terms and conditions of the Creative Commons Attribution license (http://creativecommons.org/licenses/by/4.0/). 